\title{
Front Matter: Volume 8663
}

, "Front Matter: Volume 8663," Proc. SPIE 8663, Video Surveillance and Transportation Imaging Applications, 866301 (21 March 2013); doi:

$10.1117 / 12.2022488$ SPIE. Event: IS\&T/SPIE Electronic Imaging, 2013, Burlingame, California, United 


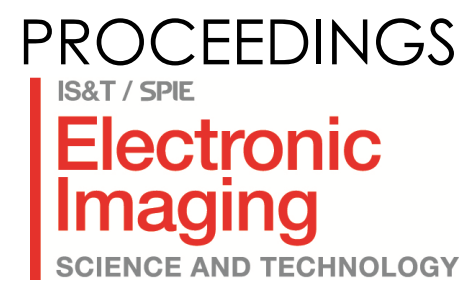

\section{Video Surveillance and Transportation Imaging Applications}

Robert Paul Loce

Eli Saber

Editors

4-6 February 2013

Burlingame, California, United States

Sponsored by

IS\&T-The Society for Imaging Science and Technology

SPIE

Cosponsored by

Qualcomm Inc. (United States)

Published by

SPIE 
The papers included in this volume were part of the technical conference cited on the cover and title page. Papers were selected and subject to review by the editors and conference program committee. Some conference presentations may not be available for publication. The papers published in these proceedings reflect the work and thoughts of the authors and are published herein as submitted. The publishers are not responsible for the validity of the information or for any outcomes resulting from reliance thereon.

Please use the following format to cite material from this book:

Author(s), "Title of Paper," in Video Surveillance and Transportation Imaging Applications, edited by Robert Paul Loce, Eli Saber, Proceedings of SPIE-IS\&T Electronic Imaging, SPIE Vol. 8663. Article CID Number (2013)

ISSN: 0277-786X

ISBN: 9780819494368

\section{Copublished by}

SPIE

P.O. Box 10, Bellingham, Washington 98227-0010 USA

Telephone +1 3606763290 (Pacific Time) · Fax +1 3606471445

SPIE.org

and

IS\&T-The Society for Imaging Science and Technology

7003 Kilworth Lane, Springfield, Virginia, 22151 USA

Telephone +1 7036429090 (Eastern Time) · Fax +1 7036429094

imaging.org

Copyright @ 2013, Society of Photo-Optical Instrumentation Engineers and The Society for Imaging Science and Technology.

Copying of material in this book for internal or personal use, or for the internal or personal use of specific clients, beyond the fair use provisions granted by the U.S. Copyright Law is authorized by the publishers subject to payment of copying fees. The Transactional Reporting Service base fee for this volume is $\$ 18.00$ per article (or portion thereof), which should be paid directly to the Copyright Clearance Center (CCC), 222 Rosewood Drive, Danvers, MA 01923. Payment may also be made electronically through CCC Online at copyright.com. Other copying for republication, resale, advertising or promotion, or any form of systematic or multiple reproduction of any material in this book is prohibited except with permission in writing from the publisher. The CCC fee code is 0277-786X/13/\$18.00.

Printed in the United States of America.

Paper Numbering: Proceedings of SPIE follow an e-First publication model, with papers published first online and then in print and on CD-ROM. Papers are published as they are submitted and meet publication criteria. A unique, consistent, permanent citation identifier (CID) number is assigned to each article at the time of the first publication. Utilization of CIDs allows articles to be fully citable as soon as they are published online, and connects the same identifier to all online, print, and electronic versions of the publication. SPIE uses a six-digit CID article numbering system in which:

- The first four digits correspond to the SPIE volume number.

- The last two digits indicate publication order within the volume using a Base 36 numbering

system employing both numerals and letters. These two-number sets start with 00, 01, 02, 03, 04, $05,06,07,08,09,0 A, 0 B \ldots 0 Z$, followed by 10-1Z, 20-2Z, etc.

The CID Number appears on each page of the manuscript. The complete citation is used on the first page, and an abbreviated version on subsequent pages. Numbers in the index correspond to the last two digits of the six-digit CID Number. 


\section{Contents}

vii Conference Committee
ix Introduction

\section{SESSION 1 VIDEO SURVEILLANCE I}

866302 Group localisation and unsupervised detection and classification of basic crowd behaviour events for surveillance applications [8663-1]

N. S. Roubtsova, Technische Univ. Eindhoven (Netherlands) and Univ. of Surrey (United Kingdom); P. H. N. de With, Technische Univ. Eindhoven (Netherlands)

866303 Gaussian mixtures for anomaly detection in crowded scenes [8663-2]

H. Ullah, L. Tenuti, N. Conci, Univ. degli Studi di Trento (Italy)

866304 Space-time correlation filters for human action detection [8663-3]

J. A. Fernandez, B. V. K. Vijaya Kumar, Carnegie Mellon Univ. (United States)

866305 Recognition of two-person interaction in multi-view surveillance video via proxemics cues and spatio-temporal interest points [8663-4]

B. Zhang, P. Rota, N. Conci, Univ. degli Studi di Trento (Italy)

866306 Weighted symbolic analysis of human behavior for event detection [8663-5]

A. Rosani, G. Boato, F. G. B. De Natale, Univ. degli Studi di Trento (Italy)

\section{SESSION 2 VIDEO SURVEILLANCE II}

866309 Collaborative real-time scheduling of multiple PTZ cameras for multiple object tracking in video surveillance [8663-8]

Y.-C. Liu, National Tsing Hua Univ. (Taiwan); C.-L. Huang, National Tsing Hua Univ. (Taiwan) and Asia Univ. (Taiwan)

8663 OA Tracking small targets in wide area motion imagery data [8663-9]

A. Mathew, V. K. Asari, Univ. of Dayton (United States)

$8663 \mathrm{OB}$ Feature descriptors for object matching in real-time tracking applications [8663-10]

G. Loibner, O. Sidla, SLR Engineering OG (Austria) 
8663 OD Ship detection in port surveillance based on context and motion saliency analysis [8663-12]

X. Bao, S. Zinger, Technische Univ. Eindhoven (Netherlands); R. Wijnhoven, ViNotion B.V.

(Netherlands); P. H. N. de With, Technische Univ. Eindhoven (Netherlands)

8663 OF An edge directed super resolution technique for multimedia applications [8663-14] O. de Lima, S. R. Vantaram, S. Piramanayagam, E. Saber, Rochester Institute of Technology (United States); K. R. Bengtson, Hewlett-Packard Co. (United States)

\section{SESSION 4 TRANSPORTATION IMAGING I}

8663 OG A smart camera based traffic enforcement system: experiences from the field [8663-15]

O. Sidla, G. Loibner, SLR Engineering OG (Austria)

$8663 \mathrm{OH} \quad$ Algorithm design for automated transportation photo enforcement camera image and video quality diagnostic check modules [8663-16]

A. Raghavan, B. Saha, Palo Alto Research Center, Inc. (United States)

\section{SESSION 5 TRANSPORTATION IMAGING II}

8663 oJ Using visual analytics model for pattern matching in surveillance data [8663-36]

M. S. Habibi, Tennessee State Univ. (United States)

8663 OK Situation exploration in a persistent surveillance system with multidimensional data

[8663-37]

M. S. Habibi, Tennessee State Univ. (United States)

$86630 \mathrm{M}$ Vehicle classification for road tunnel surveillance [8663-21]

A. Frías-Velázquez, P. Van Hese, A. Pižurica, W. Philips, Univ. Gent (Belgium)

\section{SESSION 6 TRANSPORTATION IMAGING III}

8663 ON Vehicle presence analysis for law enforcement applications and parking lot management [8663-22]

Y. Lipetski, O. Sidla, SLR Engineering OG (Austria)

$866300 \quad$ Video-based parking occupancy detection [8663-23]

M. Deruytter, K. Anckaert, Traficon N.V. (Belgium)

8663 OP Motorcycle detection and counting using stereo camera, IR camera, and microphone array [8663-24]

B. Ling, Migma Systems Inc (United States); D. R. P. Gibson, Federal Highway Administration (United States); D. Middleton, Texas A\&M Transportation Institute (United States) 
$86630 Q \quad V e h i c l e-t r i g g e r e d ~ v i d e o$ compression/decompression for fast and efficient searching in large video databases [8663-25]

O. Bulan, E. A. Bernal, R. P. Loce, W. Wu, Xerox Research Ctr. (United States)

\section{SESSION 7 TRANSPORTATION IMAGING IV}

8663 OR Vehicle occupancy detection camera position optimization using design of experiments and standard image references [8663-26]

P. Paul, M. Hoover, M. Rabbani, Xerox Research Ctr. (United States)

8663 OS Detection of vehicle occupants in HOV lanes: exploration of image sensing for detection of vehicle occupants [8663-27]

W. Daley, C. Usher, O. Arif, J. Stewart, J. Wood, J. Turgeson, E. Hanson, Georgia Institute of Technology (United States)

8663 OT Joint histogram between color and local extrema patterns for object tracking [8663-28] S. Murala, Q. M. J. Wu, Univ. of Windsor (Canada); R. Balasubramanian, R. Maheshwari, Indian Institute of Technology Roorkee (India)

\section{SESSION 8 TRANSPORTATION IMAGING V}

8663 OU Adaptive real-time road detection using VRay and A-MSRG in complex environments [8663-29]

S. H. Weon, S. I. Joo, H. I. Choi, Soongsil Univ. (Korea, Republic of)

8663 OV Intensity estimation method of LED array for visible light communication [8663-30]

T. Ito, T. Yendo, Nagaoka Univ. of Technology (Japan); S. Arai, Kagawa National College of Technology (Japan); T. Yamazato, H. Okada, T. Fujii, Nagoya Univ. (Japan)

8663 oW An improved background segmentation method for ghost removals [8663-31]

W. Hassan, P. Birch, R. Young, C. Chatwin, Univ. of Sussex (United Kingdom)

\section{SESSION 9 VIDEO ANALYTICS FOR RETAIL}

8663 OX Retail video analytics: an overview and survey (Invited Paper) [8663-32]

J. Connell, Q. Fan,, P. Gabbur, N. Haas, S. Pankanti, H. Trinh, IBM Thomas J. Watson

Research Ctr. (United States)

8663 OY Video-CRM: understanding customer behaviors in stores [8663-33]

I. Haritaoglu, Polar Rain, Inc. (United States); M. Flickner, D. Beymer, IBM Almaden Research Ctr. (United States)

$86630 Z$ Human object articulation for CCTV video forensics [8663-35]

I. Zafar, M. Fraz, E. A. Edirisinghe, Loughborough Univ. (United Kingdom)

Author Index 


\section{Conference Committee}

Symposium Chair

Gaurav Sharma, University of Rochester (United States)

Symposium Cochair

Sergio R. Goma, Qualcomm Inc. (United States)

Conference Chairs

Robert Paul Loce, Xerox Corporation (United States)

Eli Saber, Rochester Institute of Technology (United States)

Conference Program Committee

Ghassan Alregib, Georgia Institute of Technology (United States)

Raja Bala, Xerox Corporation (United States)

Farhan Baqai, Apple Inc. (United States)

Alessandro Bevilacqua, Università degli Studi di Bologna (Italy)

Philip Birch, University of Sussex (United Kingdom)

Alberto Broggi, Università degli Studi di Parma (Italy)

Yang Cai, Carnegie Mellon University (United States)

Sohail A. Dianat, Rochester Institute of Technology (United States)

Hassan Foroosh, University of Central Florida (United States)

Prudhvi Gurram, U.S. Army Research Laboratory (United States)

Mustafa I. Jaber, IPPLEX Holdings (United States)

Ned Lecky, Lecky Integration (United States)

Bo Ling, Migma Systems, Inc. (United States)

Fa-Long Luo, Element CXI, Inc. (United States)

Sharath Pankanti, IBM Thomas J. Watson Research Center (United States)

Peter Paul, Xerox Corporation (United States)

Andreas E. Savakis, Rochester Institute of Technology (United States)

Dan Schonfeld, University of Illinois at Chicago (United States)

Oliver Sidla, SLR Engineering OG (Austria)

Sreenath Rao Vantaram, Rochester Institute of Technology

(United States)

Yaowu Xu, Google (United States) 
Session Chairs

1 Video Surveillance I

Robert Paul Loce, Xerox Corporation (United States)

2 Video Surveillance II

Ghassan Alregib, Georgia Institute of Technology (United States)

3 Video Surveillance III

Mustafa I. Jaber, IPPLEX Holdings (United States)

4 Transportation Imaging I

Peter Paul, Xerox Corporation (United States)

5 Transportation Imaging II

Raja Bala, Xerox Corporation (United States)

6 Transportation Imaging III

Oliver Sidla, SLR Engineering OG (Austria)

7 Transportation Imaging IV

Bo Ling, Migma Systems, Inc. (United States)

8 Transportation Imaging $\mathrm{V}$

Eli Saber, Rochester Institute of Technology (United States)

9 Video Analytics for Retail

Myron D. Flickner, IBM Almaden Research Center (United States) 


\section{Introduction}

VSTIA I

The Video Surveillance and Transportation Imaging Applications (VSTIA) conference was new to the Electronic Imaging symposium in 2013. The conference aimed to bring together world class researchers and practitioners who develop and deploy imaging and video technologies to enable novel solutions for problems in surveillance, security and transportation. Roughly 40 papers were submitted and discussion at the conference was very lively. The conference is off to a great start in a field that is experiencing explosive growth and promises to have significant long term impact on society.

\section{Technical Field}

With the advent of low-cost/high-performance video sensors, imaging platforms, and computational equipment, it has become increasingly possible to process video streams in real-time on affordable cloud computational servers, desktop systems, and various hand held mobile devices. Major applications of these technologies span the spectrum from surveillance, transportation, remote sensing, social media, sports, retail, and biomedical to name a few. Only recently has the potential for these technologies begun to be realized in various commercial, government and consumer based applications. For instance, automated video understanding can enhance surveillance/monitoring systems beyond what is possible for human operators alone. These systems are being developed to maintain long-term surveillance on large numbers of video streams for various applications with minimal or no manual intervention. In addition, automated systems can coordinate multiple cameras and provide "synopsis" views of activities that can be used to predict/analyze potential events pre or post mortem. On the other hand, transportation systems, the life blood of our economic and social lives, are far from their ideal state. Vehicle accidents are the number one cause of death in the US for ages 4 to 34, and expected to surpass disease as a cause of death for all ages worldwide by 2020. By some estimates, half the fuel consumed in San Francisco is consumed while searching for a parking space. Vehicular congestion is a leading cause of lost productivity and the fuel efficiency considerations have traditionally received very limited attention in the design of present day systems.

Over the past two decades, various video analytics algorithms have been proposed for autonomous understanding of events for a variety of surveillance and transportation type applications. While most of the earlier solutions started from raw data and followed with the interpretation at increasing levels of semantic complexity, more recent techniques attempt to bridge the gap between signal-level and semantic level processing. Technological solutions to 
problems in these areas have the potential for very significant societal impacts on many fronts from airport/stadium/building/city security to patient/elderly care. There is an emerging global effort to develop effective surveillance systems to monitor various facilities and smarter transportation networks to improve fuel efficiency, safety, and reduce emissions and congestions in various metropolitan areas throughout the world.

Topics for VISTIA include, but are not limited to:

\section{Law enforcement}

- license plate and vehicle identification

- speed detection from stationary or mobile platforms

- seat belt enforcement

- expired registration detection

- stop/light sign enforcement

Efficiency

- shoplifting

- video-based parking spot detection for billing or navigation

- traffic congestion detection

- assisted driving/parking

- transit time estimation

\section{Environmental}

- reduction of emissions

- gasoline and chemical spill detection

Infrastructure monitoring and optimization

- traffic flow measurements

- road and bridge inspection

- snow plow and bus cameras

- vehicle classification

- vehicle conditions (overheated brakes, underinflated tires)

\section{Surveillance}

- sampling and selection techniques

- video segmentation and tracking algorithms

- event detection algorithms

- $\quad$ subspace methods for video analytics

- cooperative and context based tracking

- fusion of multiple sensors and various modalities

- Bayesian models for tracking and activity monitoring

Imaging for motor vehicles and autonomous devices

- driver alertness estimation

- road condition sensing (water, ice, dry, potholes, etc)

- road hazard detection

- object/animal/human detection

- tailgating detection

- mobile imaging platforms 


\section{Applications of the above in:}

- transport (urban/highway pedestrian/motor/mixed traffic, pedestrian traffic, terminal \port)

- retail (loss prevention, customer recognition, behavior recognition, process optimization, customer counting)

- physical security (high-density venues: concert halls, stadiums, airports, train stations, etc., and low-density venues: nuclear power plants, military installations, etc.)

- environmental monitoring (animals, forest fires, avalanches, etc.)

- smart spaces and ambient intelligence (interactive environments, etc.)

- hospitals and elder care 